\title{
The Turkish Pendulum between Globalization and Security: From the Late Ottoman Era to the 1930s
}

\section{Ersel Aydinli}

To cite this article: Ersel Aydinli (2004) The Turkish Pendulum between Globalization and Security: From the Late Ottoman Era to the 1930s, Middle Eastern Studies, 40:3, 102-133, DOI: 10.1080/0026320042000213483

To link to this article: https://doi.org/10.1080/0026320042000213483

册 Published online: 24 Jan 2007.

Submit your article to this journal $x$

Џlll Article views: 175

4 Citing articles: 2 View citing articles 진 


\title{
The Turkish Pendulum between Globalization and Security: From the Late Ottoman Era to the 1930s
}

\author{
ERSEL AYDINLI
}

The primary goal of this article is to understand the historical dynamics which led in Turkey to the emergence of a pendulum between liberalization/ globalization - at the time perceived as integration with the modern and popular west, in particular, Europe - and national security, seen as the preservation of the Ottoman lands against both external (ironically the large European powers and Russia) and internal enemies (internal in the sense of those nations and ethnic groups which aspired to be independent of Ottoman rule and which were, again ironically, open therefore to the manipulation of the external enemies). To understand these dynamics requires two main missions. First, by looking into the political liberalization initiatives of the late Ottoman era (seen in the most general sense as those attempts to share political power with the Sultan) and their relation with the tremendous public concern over the empire's security, the article explores the genealogy and formation as well as the overwhelmingly shared perception of a dichotomous relationship between security and liberalization. ${ }^{1}$ Second, by carrying out a detailed analysis of the two attempts to introduce multi-party politics during the republican era, I try to show how the previously identified dichotomy between liberalization and security developed into a 'national security syndrome', through which the democratic liberalization process would be systematically administered, managed and, ultimately, contained.

It can be argued that the Ottoman state was, by and large, a garrison state, in which the waging of war was one of the main factors behind its construction and resulting structure. ${ }^{2}$ At a time in history when the rule of the day was conquest, power, alliances and geopolitics, the Ottoman state was a true example of a geopolitical state/empire. This primacy of geopolitics made the Ottoman state a largely centralized and highly hierarchical power apparatus at the hands of the sultans, and for the most part, security issues were able to be handled quite efficiently. 
In particular towards the end of the nineteenth century, the Ottoman state began to face an increasingly destructive security problem of which the loss of lands and territories became the obvious indicator. Within the centralized state's power configurations, the grave security threat galvanized already existing tendencies and structures for further centralization in order to remaximize power. ${ }^{3}$ Unitary, centralizing power policies were perceived necessary in order to deal with the number one threat to the Ottoman Empire: military losses and subsequent geographical contraction.

This security-concerned political environment of the time also faced a second global pressure requiring a response from the Ottoman state system namely the liberalization attempts which marked Ottoman political life throughout much of the nineteenth century. In what could perhaps be labelled 'defensive modernization', liberalization/westernization was introduced in part to create a better state apparatus for coping with the destruction and defeat of the Ottoman Empire. ${ }^{4}$ Eventually, however, these liberalization ideas began to have a substantive influence on the elite. As a result, the elite began pushing for power-sharing for the sake of freedom too - though admittedly their demands were presented as being necessary in order to save the Ottoman state. What is important, however, is that liberalization/power decentralizing attempts were in fact strong, and the demands of those making them could not be ignored completely by the Ottoman political apparatus.

These increasing demands, motivated by a combination of both liberalizing efforts to increase power-sharing within the regime, and efforts to bring about greater security, ultimately sought to decentralize power in a state body, the foremost tendency of which was to remain strong and centralized. Since centralized power was represented solely by the Sultan, these decentralization efforts were based on the demands of local rulers (for example, the regional governors and local chieftains) and bureaucrats, who in earlier times had been true subjects of the Sultan, but who by now had gained a certain status and were demanding much more.

Four periods have been identified in the history of liberalization attempts in the late Ottoman era. ${ }^{5}$ The first incident is the Şer-i Huccet or Şer-i sözleşme (Ser-I contract) that was agreed upon by the new Padishah Mustapha IV, who replaced Selim, and the bureaucracts who were supporting his accession to power in 1807. In essence, the contract aimed to place certain limitations on Mustapha's power. He agreed to stay away from things 'undesirable' implying the concerns of the high level bureaucrats. In return for abiding by these conditions, the bureaucrats would retain the army which had been increasingly used to topple incumbent sultans out of politics. ${ }^{6}$

The second incident is called Sened-i Ittifak, referring to a document by the same name drawn up in 1808. The document, which focused on defining the rights and responsibilities of local powers in relation with the Ottoman 
authority, came into being at a period when various Ottoman beğs and chieftains had built up autonomous local administrations in parts of the Ottoman lands. In the most general terms, it gave these local powers the right to resist 'unjust' orders from the Sultan's administration. While many of those in the central bureaucracy signed the paper, the Sultan, and even the chiefs of the local powers themselves did not. Their failure to sign the document has led to an understanding that it was not in fact substantial in real life, except as another piece of evidence in the continuing accumulation of liberalization efforts and a memorable reference point for future attempts at reform. One interesting aspect, however, was that the demand for such a contract came largely from those local powers which were situated in the European territories of the Ottoman Empire. This trend would later be continued as European ideas and practices as well as the European origins and experiences of the Turkish elite would become the primary directional force in Turkish integration and globalization efforts with the modern world.

The third and fourth cornerstones for the Ottoman era liberalization pressure were the Tanzimat Fermanı and Islahat movements. These require a more in-depth discussion than the first two, since it is with the former that liberal power-sharing demands begin to include the rights of the people in relation to the central authority, the rights of the bureaucracy and elite in respect of the Sultan, and, later on, such concepts as freedom and equality. The Tanzimat Fermani of 1839 was a unilateral declaration by Sultan Abdulmecit, an 'auto-limitation' if you like, which curtailed the powers of the central authority through the introduction of a limited number of rights and liberties as well as the principle of upholding of the rule of law. ${ }^{7}$ With the Tanzimat Ferman 1 we begin to see for the first time in the Ottoman empire a political liberalization movement similar to those in the European nations. While the power-sharing demands of the previous attempts can be considered largely a part of the on-going power struggle between the elite and the various traditional power-holding figures, for example, local and regional governors (who enjoyed a certain amount of autonomy and desired more), the movement now began to appear more like one about the safety and freedom of the people and about the limitation of central authority - viewed as being unhelpful (if not even harmful) to the safety and freedom of the society. Even though this new emphasis was almost purely rhetorical, it was, as a start, very significant since it would help in preparing a proper environment for future, more concrete transformations, such as the 1876 constitution, which officially made the Ottoman sultanate a meşrutiyet, or monarchy. It is also important to note the salience of foreign influence in the conception and implementation of these liberalization efforts because of its pendulum-creating potential, that is, while promoting liberalization, foreign influence was also considered one of the primary sources fuelling the empire's vital security concerns. 
The Tanzimat Fermanı document was first publicly read aloud in Istanbul's Gülhane Park by Mustafa Reşit Pasha, the main architect of its contents. The document had five sections, ${ }^{8}$ the fourth of which provided the principles most relevant to this discussion. The general spirit of the five principles, on which the new laws would depend, could be said to evolve around a strengthening of the people/society against the state and rulers. The main emphasis was on the safety of life and property, the prevention of arbitrary punishment, and the introduction of various lawful procedures. 'People' in this case referred primarily to minorities as well as to the elite of Ottoman society, whose lives were often in jeopardy due to the practice of execution for political reasons (siyaseten katl), the use of which was very popular among Ottoman rulers. ${ }^{9}$

By introducing various laws and principles designed to protect peoples' wealth and property, the document was also trying to strengthen the elite of society in relation to the state. Until that time, for example, the property of those executed for political reasons was confiscated by the state treasury. Property thereafter could be inherited even in cases where the owner was executed or sentenced to long prison terms. This practice led to a gradual accumulation of wealth in the hands of elite figures other than the Sultan and thereby began creating an alternative source of power.

The Tanzimat Fermanı document also aimed at reorganizing the taxation system, and in doing so, overhauling arbitrary actions by the state that led to insecurity among the elite and society. An interesting point in the proposed 'just' taxation system was that military expenditure would be limited and carefully supervised. ${ }^{10}$ Since state power was seen largely to consis of the might and influence of the military apparatus, this is relevant to the current discussion as it indicated a direct limit of the state's power.Yet another principle limiting the state's ability to exercise powerful control over society involved military service. Until this time, the Ottoman state conscripted its subjects whenever it wanted, and for unlimited periods. The idea was introduced that conscription rates had to be balanced according to regions and that military service should be limited to between four and five years. Yet another major reform introduced by the Tanzimat Fermanı was the proposal to set up bodies resembling parliamentary councils. The members of these councils would be constituents of the military political bureaucracy and the religious elite, and thus in terms of at least some types of legislation proposals, the bureaucracy would be given a say. In a general overview, however, while the Tanzimat document introduced certain new ideas about peoples' rights in relation with the ruler, these rights would still remain mostly rhetorical for ordinary people. The true contract in this case appeared to be between the rights of the bureaucratic elite and those of the Sultan.

One of the most important characteristics of the attempts to decentralize power was that they had a tremendous foreign influence. Foreign influence 
would continue to emerge as both a rhetorical and concrete source of support in matters of liberalization and power decentralization in the Ottoman Empire. Moreover, the foreign - primarily European - influence on decisionmaking, can be seen as roughly equivalent to the early signs of a political globalization impact.

Some degree of European influence in the declaration of the Tanzimat document is largely undebated, but it is possible to go further and argue that European stimulus was a forceful factor behind the document's creation. Such a claim begins with arguments about foreign economic interests. It is argued, for example, that Britain supported the writing of this document because it was seeking to secure the rights of merchants, the elite, and the Ottoman bureaucracy, who constituted the main players in a British/Ottoman trade relationship that was very favourable to the British. ${ }^{11}$ Another argument runs that the Sultan and his government, by creating a document like the Tanzimat Ferman1, wanted to show the Europeans that the Sultan could build a regime which could be at least as liberal and modern as that of Mehmet Ali in Egypt. ${ }^{12}$ Yet a final point which supports the argument that European stimulus was an influential factor behind the Tanzimat, was the statement at the end of the document that it would be officially presented to the foreign ambassadors in Istanbul as witness of its durability. Thus it can be seen that the foreign powers were seen as a kind of 'notary' or guarantor of the laws introduced in the document, and were expected to use their power to oversee its implementation. ${ }^{13}$

The foreign role in domestic transformation was becoming the norm for the following decades. Starting in the 1850s, various waves of reform (islahat hareketleri) arose, and frequently international dynamics also played a determining role in their outcome. Most of the time, these international dynamics and pressures had direct implications of further pressure for power decentralization. While the Crimean war was being fought, the Europeans understandably did not apply their full weight to press for implementation of the Tanzimat reforms, but after the war was over, they began immediately to do so. One of the conditions included in the Paris Peace Treaty, which ended the war, was that the Ottoman state had to reaffirm 'by herself' what had been promised to the empire's minorities in the Tanzimat document. Moreover, the Ottomans were obliged to take concrete steps to further facilitate foreign economic trade. This pressure from the Europeans was met cooperatively by the Ottoman state, which on 18 February 1856 issued in confirmation a new document entitled 'Islahat Fermani' (Reform Rescript). ${ }^{14}$ This document furthered the Tanzimat reforms, consolidating the rhetoric of reform and liberalization as well as proposing concrete steps for their implementation. Among the original and even more liberal ideas that it brought with it was one stating that all Ottoman citizens, notwithstanding religious differences, 
were now considered full equals. ${ }^{15}$ The document also was the first to mention the possibility of representation of the people in local administrations and councils. ${ }^{16}$

In the period between the Islahat Fermani and the first constitution of 1876, there were other developments, which basically opened even further the Ottoman political, economic, and social space to European influence. Some examples of these were the law regarding foreigners' rights to purchase properties in Ottoman lands (1858), the sea trade agreement (1864), and the regulations about trade courts and jurisdictions (1862). ${ }^{17}$

Whilst the previous section discussed external influences along the lines of implicit pressure from the west, the following section looks at how external influences (popular ideas and practices from abroad) became internalized by local figures and transformed into an energy source for the local figures to reach their own goals.

The combination of foreign influence, material interests, and forced creation of certain institutions, accelerated the socialization of the Ottoman elite in their thinking about political rights and freedoms in line with the debates and movements occurring in Europe at the time. By the 1860s, the Ottoman elite had already been introduced to and significantly influenced by European political and cultural values. There are several factors that affected how international/foreign ideas and issues made their way to the Ottoman elite as well as how the Ottoman elite themselves accessed these ideas.

The first is that young Ottoman officers and intellectuals, already somewhat familiar with western political beliefs following the Tanzimat period, grew much closer to these ideas while fighting alongside their British and French comrades during the Crimean War. ${ }^{18}$

Another major point was that Europe was still the closest neighbour of the Ottoman capital, and Ottomans therefore regularly sent their diplomatic representatives and later their young brains to Europe for education and training. For example, the creator of the Tanzimat document, Mustafa Reşit Paşa, had been ambassador to Paris and London for many years. These years abroad enabled him to learn about Louis Philippe's liberal regime and other liberal political transformations while they were unfolding. ${ }^{19}$ He lived through, for example, the 1848 revolutionary movements, and observed the political ideas and figures. It is even said that he was personally acquainted with Lamartine, Renan, and many liberal circles in France. ${ }^{20}$ When he returned to Istanbul, he sought to convince the government to send young people to Europe for their education.

In the 1860s the Tasvir-i Efkar newspaper, owned by the poet Şinasi Efendi, became the focus for the ideology transforming Ottoman political, economic, 
and cultural life, and the important public figures promoting this ideology. ${ }^{21} \mathrm{In}$ the first issue of the newspaper, on 27 June 1862, Şinasi introduced concepts that had not been expressed before in the Ottoman world. These included 'nation', 'liberty', 'freedom', 'public opinion', etc. He referred to people's right to talk about a nation's problems and to propose solutions. The following statement illustrates best the degree to which his rhetoric included substantive reformist ideas about the relationship between a ruler and his people:

The state functions as the representative of the nation and works for the welfare of the people. The nation, through oral and written means, expresses its ideas about its welfare. ${ }^{22}$

According to Şinasi, adapting western institutions was the only efficient way to solve all the major problems faced by the Ottoman state, and by western institutions; he referred to popular western 'democratic institutions', stemming from bourgeois ideology. ${ }^{23}$

The new reformist substance of his ideas made the newspaper the centre of a growing elite intellectual group, which gradually became a movement. One figure of this group, and another contributor to the newspaper, was Namik Kemal. In his writings he too concentrated on concepts such as nation, homeland, freedom, liberty, and revolution. ${ }^{24}$ Yet another important contributor to the overall movement was Ali Süavi, and his own newspaper, Muhbir, (Informer). This newspaper concentrated largely on the question of Crete, and strongly proposed a national assembly as the only possible means of arriving at an efficient solution to the problem - thus reintroducing the idea of a parliament. ${ }^{25}$

The gradual construction of an environment of liberal ideas and the increasing number of proponents of those ideas, eventually led to the creation of an organization, the Yeni Osmanlılar Cemiyeti (New Ottomans' Society). ${ }^{26}$ This group became crucial for the transformation of the Ottoman political structure, because it was the first organization aimed specifically at dramatically changing the Ottoman state structure. ${ }^{27}$ The Young Ottoman movement was not only the first political freedom movement using western terms, but it also adopted completely western ways in its relations with Ottoman public opinion - relying increasingly on the popular press and publishing media.

The ideological support the movement gained from the European front was at a maximum at this point. Namik Kemal, for example, was reported as saying, 'The other day I talked with Gianpietri about Constitutional Monarchy, and after two hours he convinced me that we too can have a working constitutional monarchy in the Ottoman state. ${ }^{28}$ European influence and support was not, however, limited to ideological training, but included 
practical means. Frequently, the government clamped down on these groups, shut down their newspapers and attempted to persecute their members - at which times many figures were able to find shelter in Europe and continue both their ideological training and the publishing of the newspapers there. ${ }^{29}$ While organizing their activities in Europe, even the task of compiling a written directory for their organization and its members was undertaken by the Europeans. ${ }^{30}$

During the European years, the young Ottomans were able to analyse events and carry out a type of self-evaluation. Through this process they reached a consensus on the reasons why reforms on papers were not being materialized in reality, namely, they felt this was being caused by a lack of institutions to initiate the implementation process. The solution, they resolved, was a parliament. Only a parliament that represented society would be able to protect the interests of the people and therefore make the proposed reforms work. Such an institutional reform would of course require a written constitution.

Having described and diagnosed what they felt were the problems and prescribed what they saw as solutions - a constitution and a parliament - the Young Ottomans were ready to adopt them. By also adding their own strongest common value - Islam ${ }^{31}$ - to these elements, they were ready to put their plan into action. Most of the young elite were former members of the Ottoman elite bureaucracy, and it was understandable that they saw a benefit in rejoining the system that they were in fact fighting against, playing a part in that system, and then waiting for the right time to implement their plan. By the time their disliked head of government, Ali Pasha, died in 1871, most of the Young Ottomans were back in Istanbul. ${ }^{32}$

The early 1870 s brought about the right conditions for the plan's implementation. Military expenditure was out of control, and the economy was a shambles. On top of this, several bad harvests had made matters worse, and in 1875, the state declared bankruptcy. Externally, things were also going badly. Rebellions in Bosnia-Herzegovina and in Bulgaria were repressed by Ottoman armed forces and this led to protests from the European powers. ${ }^{33}$ The Ottoman state seemed trapped in both external and internal impasses.

Domestic unrest and instability reached the level of mass protests - virtual rebellions - in Istanbul. On 10 May 1876, divinity students in the capital rebelled against the government and the prime minister, Mahmut Pasha. The Sultan had to give in and make their requested changes in the government, including the introduction of new ministers. It was obvious that there was little trust between the new ministers and the Sultan, and finally, the ministers implemented a well-designed plan to force the Sultan to step down. He was replaced by Murat V. ${ }^{34}$ 
While the new Sultan was an intelligent and educated man, open to liberal thoughts, he also had psychological problems of paranoia, based on his fear of being killed by his rivals. By the time the first Balkan wars were about to begin, powerful ministers obtained confirmation from the chief religious leader (Şeyhülislam) that the Sultan was too sick to perform his duties. Prince Abdulhamit, who became the new Sultan on the condition that he accepted the constitution, thus replaced Murat V. ${ }^{35}$ This constitution was an important step in the guaranteeing of some degree of power-sharing/decentralization within the Ottoman governance system.

Liberalization, or power-sharing attempts, did not take place in a vacuum. In fact, there were several other issues, such as the economic situation, political rivalries, etc. which affected these efforts. Perhaps the most significant concern in the public sphere in the late Ottoman era, and therefore also bound to have an influence on liberalization efforts, was that of the external and internal security concerns they faced. The state was continually losing its territories, and it seemed there was nothing to be done to stop this process. The main question addressed by many, therefore, was how to protect and save the country from these external and internal attacks. In the following I discuss how the acts and needs for liberalization interplayed with those for national security, and thereby introduce the dynamics and character of the gradually forming dichotomous relationship between liberal reforms and national security issues.

Attempting to carry out liberal political reforms at a time when the survival of the state was increasingly at risk created a very complicated relationship between these two great pressures facing the Ottoman state. It should be noted that most of the time the security of the state enjoyed a clear primacy over the liberalization efforts, resulting in a kind of 'reserved' westernization that contradicted fundamentally the ideal forms of liberalization/westernization ideas. ${ }^{36}$ This may explain why the liberalizers generally made great efforts to express their proposed liberal reforms as ways of 'protecting the state/nation' from external defeat and gradual territorial contraction. This initial characteristic would ultimately have very important implications, since liberalization efforts were generally seen as a means of reaching the primary goal of protecting the security of the Ottoman state. ${ }^{37}$ One of the clear indications of this nature of the relationship is that the reorganization of state power in terms of limiting the Sultan's powers, was not directly in favour of the masses, but rather in terms of creating power-sharing between the Sultan and the bureaucracy, whose primary job was to prevent military defeat of the state and put an end to territorial contraction. In a sense, power reconfiguration was sought in order to give further rights and prerogatives 
to those who could best provide for national security needs. At least, this was the main rhetorical justification for power-sharing demands. One can even argue that the bureaucrats were only able to force the Sultan to share power because he was unable to perform well his job of providing security, or at least not as well as the previous eras had witnessed.

Evidence of how security concerns were used to support liberalization can be seen in the Young Ottomans' famous letter from Paris. In this letter, written by Mustafa Fazil Pasha and published in the form of an open letter to Sultan Abdülaziz in 1867, it was pointed out that 'most of the problems and underdevelopment could be overcome by freedom' and that the 'lack of freedom makes it much easier for the European powers to work against the Ottoman state by intervening in its domestic affairs'. ${ }^{38}$ Invested in the liberalization efforts is obviously hope for the 'good old days' of security and welfare. The ultimate goal can be seen as one of stability and security, in which context room could be found for modernization.

Yet another indication of prioritizing security over liberalization can be seen in the administrative reforms introduced by the Tanzimat document. Whilst the liberal political proposals it introduced would not be implemented in reality for a long time to come, certain administrative reforms, introducing total centralization of government power, took effect very quickly. The periphery of the Ottoman state was put under further control with the introduction of a French system of appointing governors and district administrators from the centre. The state was divided into governorships, which were in turn divided into districts, and again into villages. One security chief and two administrators were also assigned from the central government to assist the governor. ${ }^{39}$ Such a heavy central authority was clearly able to supervise and indeed control the newly introduced local councils, which were made up of local people. This tendency to introduce one policy in order to balance new powers emerging from another new policy of liberal reforms points to traces of a dichotomous relationship between liberalization and stability/security, as well as to mistrust of the central authority over its subjects, that is, ordinary people and their political representation.

To many it seemed that power decentralization was obviously making the state's internal affairs more open to foreign involvement, and was therefore creating a security problem. The resulting mistrust of the various nationals, citizens and societies of the Ottoman empire was perhaps best revealed when the liberal bureaucrats replaced Sultan Abdulaziz by Murat V, yet throughout the process no mention was made of a constitutional monarchy. When, after the successful coup, one of the liberal ministers, Suleyman Pasha asked, 'if we were not going to declare the constitutional reform, why did we overthrow the Sultan - to get a new one?' The prime minister answered, 'the people don't have the quality for a system based on their desires and representation'. 
Another minister went even further, saying that, "the state trusts you [the bureaucrats], will you go ask the ignorant Turks of Anatolia and Rumeli about the important affairs. . about security? ${ }^{40}$ Fear of society's potential in terms of state affairs and bureaucratic mistrust in the fragmented characteristics of society, were apparently present from early on.

One other major characteristic of the relationship between liberalization and security was that the elite, whose primary intellectual interest was to liberalize the state, also happened to constitute the primary group whose job it was to protect the country's national security, and to prevent its territorial contraction. At first, liberalization was considered to have either a potentially positive or merely irrelevant effect on security. Later on, indications were that liberalization efforts in and of themselves might be creating security problems, such as leading to self-determination movements among minorities, and the consequent foreign manipulation of these. As long as the needs of both missions were in conflict, the elite had to come to terms with the true nature of the dichotomy and were forced most often to make a choice. At the beginning, they were perhaps able to avoid seeing the conflict by convincing themselves - and trying to convince others - that liberal reforms could in fact bring about unity, stability, and security. Such a tactic was risky, however, because in the event that liberal reforms did not bring about security and welfare, they would then be considered unsuccessful, and would have to be dropped from the agenda - with no one else there to continue promoting their implementation.

Drawing up the 1876 Constitution signified a turning point in developments for placing some degree of limitation on the ultimate central authority of the Sultan. The 1876 constitution was a true reflection of the above-mentioned philosophy adopted by the elite, revealing a belief that since Europe, with her various institutions, was successful at home and abroad, then these same institutions should logically bring about similar results in the Ottoman empire. Imitating the west, and relying on whatever means of European influence were available, were again the primary motivations behind the 1876 constitution.

There are several points that show the salience of external factors leading to the 1876 constitution, principally the year 1875 which saw an unprecedented economic crisis in the Ottoman economy. Combined with minority rebellions in the Balkans and European intervention due to reopening the debate over the 'eastern question', this economic crisis led to serious political struggles. In the ensuing debates over which way the Ottoman state should head in terms of its international relations, Sultan Abdulaziz and the Russian ambassador supported keeping the Ottomans as part of Asia and resisting the Europeans, whilst leading bureaucrats and the European powers took the opposing 
position of trying to anchor the Ottoman government firmly on the side of the Europeans and their great power politics.

At the same time that the European powers, via their diplomatic representatives in Istanbul and their domestic allies among the Ottomans, were preparing to replace the Sultan, they were also organizing an international conference to be held in Istanbul in 1876 on the future of the 'eastern question' and the future of the rebelling Balkan nations. This conference, popularly known as Tersane Konferans1, was fiercely opposed by the Ottomans fearing that it would be used by the independence-seeking nationalities within the empire to capitalize on western help in their struggle against the central power. ${ }^{41}$ When the Sultan was replaced and the constitution of 1876 was declared, the news was rushed to the Europeans in the hope that they would cancel the conference. The argument ran that the Ottoman state now had a constitution - something that did not even exist at that time in Russia - and therefore there were no points left to discuss about the Balkan nations' rights and other issues on the conference agenda. By accepting the constitution, the Ottomans hoped, among other things, to stop what they considered to be European manipulation of Ottoman security issues. The Europeans did not agree, and the Turks withdrew from the conference. ${ }^{42}$ As is obvious, once again liberalizing turning points were very much intertwined with the national security of the Ottoman state, and, as was argued earlier, liberalization was seen as a means of meeting national security needs.

The nature of this liberalization/security relationship was also clearly reflected in several parts of the 1876 constitution - some of which would ultimately prove fatal for the constitution itself and for the newly established parliament. One example was that the only part of the parliament with elected representatives, the Heyet-I Mebusan, was largely impotent, and was surrounded by more powerful institutions, which were not democratically elected. ${ }^{43}$ In other words, this constitution was not based on the principle of power separation, but rather on the continuing primacy of the non-elected segments, whose primary goal and concern was national security.

Whereas the 1876 constitution provided a progressive agenda in terms of judicial processes and personal liberties and rights, ${ }^{44}$ it simultaneously introduced a few crucial exceptions to the liberal rhetoric, which basically nullified all other progress made. For example, Article 113 gave the Sultan right to declare an emergency situation in order to postpone (indefinitely) constitutional rights and to send into exile anyone found to be a danger to state security. This created more room for applying security issues as tools in domestic political power struggles. Another example, article 36, also allowed that when the parliament was on holiday or during times of emergencies, the prime minister could make any decision to protect the security of the state without having to ask the permission of parliament. One other point was that 
the 1864 provincial reforms, giving more central authority control over local developments, were also given a place in the constitution. ${ }^{45}$ It was obvious that the power decentralizing impact of possible liberal political aspects of the constitution was being balanced by various centralized control mechanisms.

The constitution had also held the promise of averting a war with Russia, who was complaining about the conditions of Slavic minorities living under Ottoman rule. The hope had been that the constitution would remove Russian justification for intervening in the areas of Slavic minorities, in other words, remove a cause for declaring war on the Ottomans. The promise failed to hold, however, as the Russians nevertheless declared war in 1877. Once it was clear that the declaration of the constitution would neither prevent the probability of war with Russia nor the increasing foreign involvement in Ottoman domestic affairs (in the sense that the Conference had been conducted despite the constitution), the Sultan first decided to appeal to Article 113 of the new constitution and get rid of the prime minister ironically the primary individual behind the creation of the constitution. With the prime minister out of the picture, the Sultan then took advantage of the 1877-78 Ottoman-Russian war in order to dissolve the parliament. The parliament and the constitution were sacrificed mainly due to their failure to bring about security and defence against foreign involvement. This is of course hardly surprising, since the entire liberalization process and the declaration of the constitution can be seen largely as a means of defending the country, and when they did not work, they had to be dropped. The Sultan was then given the opportunity to try his own method of achieving the same goals, one of which was the most traditional means of securing the state: absolute authoritarianism (istibdat), which lasted for roughly the next 30 years.

The primacy of security and authoritarian methods to achieve more centralized power, and thus better defensive capacity in the constant wars against external enemies and internal rebellions, overwhelmingly determined the nature of the period between the 1876 constitution and the foundation of the Turkish Republic in 1923. Granted, there were certain periods in this era in which we see a return of the constitutional monarchy. In the case of the 1908 movement, for example, this was even a bottom-up movement including the broad elements of society as opposed to merely the elite. Nonetheless, the main characteristic of this period - in terms of the liberalization/security dilemma - was one of constant political struggle with the sole purpose of being able to fight better against foreign enemies and territorial contraction. Even the rhetoric of freedom and liberalization that came after the 1908 coup and reintroduction of the constitutional era ${ }^{46}$ lasted only a few months. The rule of the day soon became Jacobean policies aimed at centralizing authority, and in essence authoritative policies of the Sultan 
were replaced by authoritative policies of the İttihad Terakki Cemiyeti ${ }^{47}$ (Society of Union and Progress). This era has been nicely described as one in which the liberal wing of the Young Turks lost the battle to the authoritative elements, whose primary aim was to protect the state and who would never consider liberalism as a means and in fact more likely saw it as a weakness and danger to state security. ${ }^{48}$ The regime became a semi-military one, in which years were spent trying to suppress political elements and conducting defensive - sometimes offensive - wars against external enemies.

The Ittihad ve Terakki Cemiyeti's somehow successful efforts to centralize power were largely by provoking Turkish nationalism and thus attaching the idea of nation (Turkish) to efforts to protect the state.

Once the complexities of carrying out liberal transformations in the context of a highly fragmented, multi-national societal structure and constant threat of war and insecurity were fully recognized, the Ottoman state elite turned to the trend to nationalism as a means of responding to both security needs and liberalization drives. It became clear that 'Ottoman citizenship' or some form of multi-cultural constitutional democracy would not be adequate to secure the Ottoman lands and successfully modernize and transform the state and society. Most of the minorities or ethnic populations of the empire were turning the energy of liberalization/modernization trends into nationalist projects in order to build up their own nation states. Under these circumstances, the Ottoman state elite also began developing its own nationalist project based on 'Turkishness'. In essence, the goal remained the same - to preserve and protect the homeland - but the scope and concept of the homeland was somehow smaller.

It is very important to note that this nationalist project was in fact a very modern one, in which a nearly perfect combination was often reached between the two determining forces of the public discourse and agenda, namely, security/stability and liberalization/ modernization. In other words, protection of the homeland while simultaneously transforming and modernizing it was perceived as highly possible under the nationalist ideology. ${ }^{49}$ Starting with the İttihat Terakki and peaking with the foundation of the Turkish Republic, nationalism seemed to have found a way of modernizing/liberalizing while insuring safety and security. At the beginning of the İttihat Terakki, through the First World War and the War of Liberation, security was clearly seen as a necessity, and therefore liberal modernization efforts were thought secondary. Once the nation and the state elite began to feel that they had reached their goal of protecting the homeland and securing the safety of the transformation from absolutist regime to republic, the deeply rooted desire for liberalization resurfaced. Of course, in this new period the 
understanding was that the borders of liberalization were still determined by national unity and security.

In the early part of the twentieth century, the Ottoman Empire and subsequent young Turkish Republic experienced a period marked by much warfare from the late Ottoman wars in the Balkans and the First World War, to the Turkish War of Liberation. As the early 1920s came and the wars came to an end, the ruling elite that had established the new Turkish republic began to feel more in control. The major internal and external security challenges had, at least for the moment, been met.

This section of the article explores how this globalized/western-integrated (intellectually and in spirit) Turkish state elite, once they felt they had secured their state, began pushing for further liberalization. Their efforts, however, failed to go beyond the previously identified dichotomous relationship between political liberalization and security. Moreover, the failure of these liberalization experiments can be argued not only to have consolidated their perceptions of a zero-sum gain between political liberalization and security, but also to have turned the dichotomy into a national/ regime security syndrome. This development is perhaps best illustrated by looking at the two early attempts that were made at multi-party politics and their effect on the system. The following section shows how much of the political discussion in the early republican era, even that about non-security issues like democracy or corruption, ultimately became securitized, ${ }^{50}$ that is, seen as threats to the republican regime, as the national security syndrome took hold.

After Atatürk dissolved the Grand National Assembly on 15 April 1923, nation-wide elections were held over the months of June, July and August of the same year. The candidates' political records and qualifications were closely scrutinized by Atatürk, and consequently a parliament consisting largely of Atatürk's chosen candidates was produced. ${ }^{51}$ Yet seeds of opposition to the ruling elite and their vision of governance were nonetheless present in the second parliament of the republic, and were growing more vocal. This was largely due to the revolutionary changes that were being made, including the declaration of the republic itself, and consequent resistance to them. The opposition was primarily built around the army pashas (generals), who had previously worked closely with Atatürk, namely, Refet Pasha, Kazim Karabekir Pasha, Ali Fuat Pasha, and the former prime minister (and apparent leader of the opposition group) Rauf Bey. The opposition's arguments were also supported by some of the press, primarily the large Istanbul newspapers. Atatürk saw the potential for a strong opposition among the generals, who could draw on the prestige of their 
military backgrounds within the political arena, and therefore force them to choose between parliament posts or military ones. They all chose to become civilian parliamentarians - thus creating the potential for an opposition via politics and the parliament. It can of course be argued that the domestic power struggles were the primary driving source in creating a second political party, and that the rhetoric of seeking a more democratic governance system was nothing more than just rhetoric to help the opposition forces gain a foothold for their struggle. On the other hand, genuine discussion about democracy was definitely present and influencing the process to some extent. The prominent journalist, Hüseyin Cahit, of the daily newspaper Tanin, for example, wrote at the time that 'the current dominant single party is only paying lip service to democracy...the republic is not a true republic if it is not based on democracy'. ${ }^{52}$

Before an actual second political party was formed, the nature of the opposition to a second party from the members of the existing political party, Atatürk's People Party, became apparent in everyday political debates. For example, a parliamentary inquiry in 1924 into corruption charges concerning the population exchange between Greece and Turkey, turned in fact into a struggle between the government and opposition forces. Against each of the charges raised by the opposition, the representative members of parliament for the government insisted that the opposition's views were actually about being anti-republican and even pro-sultanate. ${ }^{53}$ Although leaders of the opposition declared repeatedly that they were in favour of the republic, national independence and liberties, explaining that 'national liberty is the real source of the republic not the other way round, ${ }^{54}$ the debate had already become one of regime security, with a tendency to create pro and anti elements.

The government elite preferred to concentrate on out-of-context extracts of opposition speeches, such as 'the declaration of the Republic is rushed', rather than on broader opposition statements such as 'we became MPs in order to establish the system of democracy, not to pass this authority over to the hands of institutions that are not directly responsible to the society'. ${ }^{55}$ The first episodes of the debate between republic and democracy had begun, and the republicans were determined to use the shield of regime security in their struggle against 'democratic' arguments and their proponents. This tactic seemed to pay back when, for example, an influential MP from the side of the governing elite, and owner of the influential newspaper Cumhuriyet, said that he would support the government's side on the alleged corruption charges made against it because 'the republic was at stake' and 'there was no need to confuse the minds of the public with the debate about which comes first republic or liberties'. ${ }^{56}$ Finally, all the charges were ignored, and the parliament protected the government in the name of protecting the regime and its security. 
Despite the resistant environment, the Progressive Republican Party (TCF) was founded on 17 October $1924 .{ }^{57}$ Immediately thereafter, the existing Peoples' Party also adopted the adjective 'republican' in its titlel, indicating the sensitivity to the regime debate mentioned above.

At least in rhetoric, the new party had come into existence in order to expand radically the democratic dimension of the republic's governance system. The party programme went as follows:

We are strongly in favour of general liberties and rights... individual liberties and consequent debate will fix the defects that exist in our public system. . .Individual liberties will be effective at every level. ..In order to show our sincerity about individual liberties and freedom we will have a high level of within-party democracy. ${ }^{58}$

As opposed to the existing Republican People's Party (CHP), which seemed to represent the authoritative dimension of the liberalization project $-\mathrm{a}$ characteristic stemming from the Tanzimat period and therefore seen as the extension of the İttihat Terakki tradition - the TCF was clearly representing the liberal, democratic dimension of Ottoman-Turkish integration with western political norms. ${ }^{59}$ It should therefore be noted that even though the initiation phase of this party can be partly explained by domestic power struggles, its main philosophy and the energy upon which it drew for support came from an effort to instil more deeply the effects of political globalization on the way to western-style democracy. In rhetoric at least, the TCF was seeking a deepening or consolidation of the political transformation that had long been sought, and had finally been reached - on paper.

As was noted, the struggle between dominant and challenging ideas was forced into being based on a largely perpetuated concept of regime security. Unfortunately, there were at this time events taking place in Turkey to which the security-minded elite could point and then forcefully claim that not only the regime but the very state itself was at stake. This meant virtual death knells for the democratic elite and their arguments. The Kurdish rebellions and the state response to them would bring about a securitization period both in public discourse and action, and once again attempts at political globalization would be sacrificed in the name of stability and security by a security-minded elite.

Once the insurgency movements began in south-east Turkey, the CHP leader, Prime Minister İsmet İnönü, asked for a declaration of emergency. The rejection of his proposal by parliament led to his resignation. A new cabinet was formed, headed by Ali Fethi Okyar, who had a 'softer' approach towards managing the rebellions. ${ }^{60}$ As will be shown in the following, however, the way incidents progressed, and the manner in which Atatürk and 
elite opinion treated and reacted to these developments, paved the way for future hawkish policies and politicians - such as would be expected under a national security regime. Security-minded politicians were present and ready to retake the government in order to crush the rebellions - once again at the expense of many liberties.

There were several Kurdish rebellions in both the Ottoman period and in republican times. ${ }^{61}$ Some elements of Kurdish society - inherited from the late Ottoman times to the republican era - were not readily willing to be subordinate to the regime and policies of the young Turkish republic. Starting with the republican period, several Kurdish groups wanted to have more control and autonomy in their affairs. Among these, in particular, were the remaining members of the Hamidiye Alaylari, or the forces of Abdulhamit who had been recruited primarily from the Kurdish tribes in order to fight the advancing Russian armies and cooperating Armenian rebels. While it is unnecessary to give extensive details about the reasons behind these Kurdish rebellions throughout history, it is important to note that these movements were at least partially stimulated by the emerging nationalist tendencies prominent in the world at the time. The important factor is that the Ottoman/ Turkish modernization project as a nation-state with a centralizing agenda was disturbing to Kurdish elements that were accustomed to some - and wanted even more - local autonomy. It can be argued that, ironically, Kurdish demands for more autonomy were in part the result of political globalization (in the sense of nationalism at the time) and at the same time of helping to create a basis for the governing elite to resist the effects of further diffusion of that same force for political globalization.

The Turkish revolutions - the removal of the Caliph and the Sultan and the emerging Turkish characteristics of the new republic - even further incited the existing insurgent potential of some Kurdish figures. When Sheik Said announced his rebellion in 1925, several other tribes joined him, constituting a substantial front that was able to begin taking over power in some small towns in south-east Turkey. Military developments in terms of how the rebellion progressed and the Turkish military responses will not be discussed here since it is the political implications that are relevant to the topic. Suffice it to say that the Turkish side, with some help from the French government, was able to mobilize a large number of troops to the region, thereby changing the military balance in the region in favour of the government forces. The rebellions were suppressed, and the leaders, including Sheik Said, were caught and executed in April 1925. ${ }^{62}$

The political implications of the rebellions and, perhaps more importantly, of the state's responses, are important to analyse. The government of Prime Minister Fethi Okyar, relying on the constitution, declared emergency law, and appealed to the parliament for confirmation. He supported his reuest by 
pointing to the possible external/internal links in terms of the real causes behind the rebellions, referring to the agreement plans for the southern border with foreign powers such as Britain. His understanding that the rebellions may have had external support received wide backing in the parliament, including that of its chairman, Kazim Karabekir Pasha, who said that, 'everybody should know that all the children of this homeland will unite, be ready to make any sacrifices in order to stand against internal and external enemies ${ }^{6}{ }^{63}$

Despite the declaration of emergency law, a sense of insecurity seemed to be growing. From leading local figures in every corner of the country, Atatürk received telegrams condemning the rebellions and pledging support to the government. ${ }^{64}$ A national campaign for complete national security and stability was being formed. Such an environment in which the primacy of security was now deemed absolute, was seen as a golden opportunity for the hawks who thought that the state was at stake and that the then prime minister was too soft and 'democratic'. The hawks strongly criticized the government's attitude in parliament. In the name of security, huge political changes could be rushed through with little debate, and once Mustafa Kemal had also voiced the opinion that a harsher response to the rebellions was necessary, a new hawkish government, again headed by the security-minded Ismet İnönü, promptly took over. İnönü's opening speech in the new parliament signalled the coming period of increased security and a slowing down of democratic movements. 'We will take every measure in order to crush the recent events quickly and forcefully and to protect our homeland from any chaotic situation. This will be done to strengthen and consolidate the state's power. ${ }^{65}$

İnönü's government immediately introduced a proposed law, known later as 'Takrir-i Sukun' (Reconstruction of the Calm). The law's overarching main article, which could be used arbitrarily to block any political activity, stated that 'the government can - with the confirmation of the president forbid and abolish any institution, behaviour, and publications which disrupt the country's social order, calm, security, and safety'. ${ }^{66}$

Many liberal parliamentarians opposed the authoritative, dictatorship-like proposal. One parliamentarian said in response that combating the rebellions should be done 'with respect to the people's individual rights and safety'. Yet another, representing a region in which there was rebellion, remarked bitterly that, "there is no concept in the world as big as national safety and order, especially the word security, such a concept that arbitrarily can include even the thoughts in people's brains'. Still another parliamentarian pointed out that 'the arbitrary potentials of such a blanket law meant that the government did not trust its nation'. ${ }^{67}$

Government representatives, such as the defence minister Recep Peker, rejected this last accusation, saying that there were 'realities' and these realities should not be allowed to disappear among the idealist and 
philosophical theories - suggesting that democratic approaches in response to threats were only a delusion. Meanwhile, the justice minister reiterated the idea that the law was necessary in order to block the growing anarchy in the country. Ultimately, the irresistible supremacy of security over liberal political approaches became evident, and the law was passed with a significant majority.

Along with the law for 'reconstruction of the calm', two wartime type tribunals with extraordinary powers were also established in the mid-1920s. One was to handle cases within the rebellion zone, but the second was given jurisdiction extending beyond the rebellion zone, and could therefore be considered indicative of the state elite preparing to take authoritative measures across the country, in other words, more extensive security ${ }^{68}$ Using the new tribunal, the government quickly closed several newspapers that had taken a position largely independent of the dominant government view. ${ }^{69}$ Even after the rebellions were under control, the emergency laws including the tribunals continued, allowing the security-minded hawkish elite to take care of various problems they had been concerned with earlier. All measures were undertaken expressly for the security of the state and the regime. Nothing, not even the opposition party, whose democratic ideas and proposals meant little in public opinion at a time of widespread security, could resist such a major drive.

The general mood of the more security-minded ruling elite at the time seemed to be determination to use the opportunity to eradicate all political alternatives and potential opposition. At the peak of its activity, in 1926, the war-time tribunal (Istiklal Mahkemesi) sent a note to the chief prosecutor's office, saying that it had been proved that the Progressive Republican Party had used propaganda and activities based on political Islam in its political interest, and that the government should be informed about this. The chief prosecutor's office lost no time in passing the note to the government, which in turn applied the Takrir-i Sukun law and closed down the TCF in order to protect the people from 'being provoked'. ${ }^{70}$ Clearly the government was not prepared to entrust the people with further liberties, believing that such liberties could be manipulated and pose risks to the regime and to state security.

There is little doubt that the security-oriented, statist elite used the security process, but it is less clear whether the fear for the security of the state and thr regime was based on genuine or merely constructed perceptions of danger. The fact is that the implementation of the dictatorship-like laws continued long after the immediate danger of the Kurdish rebellions had been suppressed, ${ }^{71}$ and was used to curb not only attempts at power by the political elite, but also Islamic and left-wing movements. ${ }^{72}$ It is also clear that this practice of appealing to security issues would become the expected form 
of behaviour of the dominant security-oriented elite in its future relations with democratic forces.

There are two main arguments to explain why, by the early 1930s, Atatürk wanted to promote the formation of an alternative party and make another attempt at multi-party politics. The first is that after five years of intensive transformation, including major reforms of dress code, the alphabet, etc. and a period of iron rule by a single party with little economic success, the opposition in society had been provoked. Had this opposition been allowed to continue uncontrolled by the state, it might have led to collapse of public order, ultimately threatening the power of the state and regime. A new party attempt to channel the opposition in more manageable directions could have seemed highly desirable. ${ }^{73}$ Certain leaders of the newly created Free Party (Serbest Firka) reported having had doubts themselves about the possible validity of this argument. ${ }^{74}$

On the other hand, it could also be argued that Atatürk was an idealist in terms of developing the nation's republican structure into a democratic one, and was in fact seeking opportunities to acclimate Turkish society to true notions of democracy. The same Free Party leader cited as supporting his doubts reports in his memoirs that Atatürk personally offered to him the following reasoning behind his decision to ask him to start the Free Party, 'Our new republic does not look that impressive. I am a mortal, before I die I want to see my nation accustomed to real freedom and democracy, and for this there is the need for a new alternative political party. ${ }^{, 75}$ Moreover, in a speech to parliament during the period of the Free Party, Atatürk stressed three issues which he felt should be emphasized at that time: justice, economic policies, and 'untouchable' election freedom, and he supported his calls for freedom of the press by saying it was the way to achieve a 'more democratic government'. ${ }^{76}$

Whatever the case, he was clearly attributing great importance to the multiparty attempt. A major factor that may have forced him into this position was the external image of the Turkish elite. It is reported that there was increasing discontent among some of the Turkish ruling elite that Turkey's single-party system indicated inferiority compared with western democracies. Mustafa Kemal particularly felt increasing discomfort with western criticisms about this issue. ${ }^{77}$ Moreover, it has been reported that the speaker of the Turkish parliament told Mustafa Kemal and Fethi Bey that it was 'really embarassing' to try to defend the single-party system when he was in Europe. The report also states that Mustafa Kemal was very pleased with the positive reactions from the west in respect of the Free Party attempt in Turkey. ${ }^{78}$

Probably Atatürk was pushed to seek further liberalization by a combination of these factors. Whilst he always had in mind a historical project of transforming the country along the lines of western systems of 
government, he was also very practical, seeking to avoid risk, and might be expected to set up an easy control mechanism to secure the country's transformation in the face of circumstantial challenges. In fact, in the course of this experience, Atatürk would reflect this split, being torn between further liberalization and the stability and security of the governance system, as well as the safety of the elite who had managed to bring about the existing level of Turkish integration with western norms. For the present argument what is important is the outcome of the second multi-party experience, the tragedy of which served to solidify the already budding national security syndrome among the state elite.

Fethi Bey, former prime minister and later Turkish ambassador to France, as well as a close personal friend of Atatürk, wrote a letter to Mustafa Kemal in the spring of 1930. After giving his opinions on the problems in Turkey, he drew on his observations about democratic developments abroad to make certain recommendations for improvement:

In order to consolidate and further the republican regime in Turkey, instead of having a single party system [we need] a multi-party system that will establish freedom, debate, and control over the government about its policies vis-à-vis society. With your permission, I intend to enter politics with another party in order to reach this goal. ${ }^{79}$

In his response, Mustafa Kemal stated his agreement with the ideas:

Since my youth I have been in love with the idea of a system which would control and check government affairs. During my tenure as president, I assure you that with all my power and responsibilities I will treat every political party equally, staying within the parameters of the secular republican system. Your party won't have any obstacles. ${ }^{80}$

Following this exchange, Fethi Bey came to Istanbul on two months' leave from his post as ambassador. He met Mustafa Kemal, who repeated his views, adding that the current system looked like 'a dictatorship', and that he did not want to leave behind such an authoritative system. ${ }^{81} \mathrm{He}$ reemphasized his only reservations, a sensitivity to the republican regime and to secularism. This may be why he entrusted this mission only to his closest friends, thus choosing Fethi Bey, whom he probably felt he could count on to recognize and appreciate the line between liberalization values and risks to the regime and state.

Once agreed, the procedures were quickly drawn up, and the party was established on 12 August 1930. By its nature the party was clearly in favour of liberalism. One of the founding figures, Ahmet Ağaoğlu, whom Mustafa 
Kemal strongly encouraged to become one of the party founders, was a wellknown firm supporter of liberal economics and politics. Even the very name of the party itself (serbest means free) referred to freedom and free politics.

The Free Party soon began receiving a tremendous amount of positive attention from society ${ }^{82}$ and also support from some newspapers. ${ }^{83}$ Unlike the case of the first multi-party attempt and the resulting TCF, which to a large extent had come about as the result of an internal power struggle among the ruling elite, the Free Party began to receive support from society. For the first time a true mobilization of the masses seemed possible, and the ruling elite saw the potential for a movement that could really threaten the status quo and the goals of their revolution.

When the leadership of the Free Party travelled to the city of Izmir, the local CHP city administrators tried to block their coming, nevertheless the support of the people was overwhelming. ${ }^{84}$ The Free Party slogans of 'long live the free republic' and 'long live the free country' also reflected what the people saw in this party, or what they wanted from it for themselves. It began to appear that the party was more than just an alternative political party competing in parliament, but a people's revolutionary movement, that could possibly take over the entire state.

It was said that the party came to represent everything reactionary to the existing system. ${ }^{85}$ The then prime minister, Ismet İnönü, commented on this:

Everybody who was against the Atatürk administration and my government due to the rapid revolutionary reforms such as the dress code, and to the relocation of some people due to the eastern rebellions, they all found a common place and shelter in this party. ${ }^{86}$

His thoughts are supported by evidence from some Free Party gatherings and demonstrations, in which slogans against secularism and demands for reversing the more revolutionary reforms were in evidence. ${ }^{87}$ It was even alleged that 'anti-revolutionary elements' were taking advantage of the party and trying to 'hide behind the nice name of the party [and] poison the society against the government/state'. ${ }^{88}$

More important than the personal historic accounts of what happened, is the evidence of how the state structure and elite reacted to the Free Party experience. The ruling elite had first thought that a small, weak alternative would strengthen their own party's image in society. When it became clear that the new party was poised to become a truly competitive one, a kind of panic broke out among the ruling elite. ${ }^{89}$ The CHP immediately established a 'counter-struggle group', consisting of 40 deputies in control of several state functions. ${ }^{90}$ Thus the party began using the "state machine" ${ }^{91}$ to block the new party's progress. When, for example, the Free Party leadership was 
planning to make an important trip to Izmir, the CHP governor of the city refused to provide even basic services, such as some security arrangements. ${ }^{92}$

The security-minded bureaucracy and the CHP elite quickly resorted to measures similar to those in the first multi-party attempt, and brought charges against the Free Party about threats to the regime and to state security. Referring to dissident elements among the Free Party's supporters, the ruling elite revived the debate over the republican regime, secularism, and the safety of the country. ${ }^{93}$ Finally, a leading parliamentarian and owner of the proregime newspaper, Cumhuriyet, wrote in that paper an open letter to Mustafa Kemal on 9 September 1930, demonstrating that the security surrounding this political issue was almost complete. 'Some other parties are trying to show that our chief, Mustafa Kemal, is on their side; even if that might be the case, we [the CHP and the state elite] have a life mission to protect the republic and are ready to defend it under any condition' (italics mine, E.A.). ${ }^{94}$ It was obvious that the power of the status quo was based on linking the elite's interests to those of the regime and state. Without this, it would have been extremely difficult to send such a threatening message to the founder of the republic in the name of that republic.

Once again, the state elite preferred to emphasize the security of the regime over the arguments for liberalization in the debate. Their approach and emphasis on the security dimensions of public life produced a rhetoric which basically argued that further attempts at democratization, including a role for the society greater than that of the state, would bring anarchy and insecurity. The Free Party, on the other hand, was trying to argue that if the state apparatus would refrain from taking sides or otherwise intervening, then politics (elections) could take place in a normal way, and there would be no need to worry about security and stability. The following dialogue between Mustafa Kemal - who seemed at the time to suscribe to the elite's security campaign - and a leading Free Party figure, clearly shows the faultlines between security and political liberalization:

Ağaoğlu: M pasha, we [the Free Party] would be more successful if the police and the state forces didn't openly block us and side with the other party...

Mustafa Kemal (somewhat angry): Efendi, anarchy is emerging everywhere. The people hit the army commander on the head in Antalya, he's a patient guy, if it were me...

A: Pasha, what was the commander doing in the polling station?

MK: He was there to stop the anarchy.

A: No, anarchy emerges because he goes there in order to block a free election. People go there to vote, and what they see are soldiers in front of them. 
MK (very angry): Anarchy, there is anarchy everywhere, you are oblivious or blind to this fact. . how can you expect me to be impartial then (about political parties)? ${ }^{95}$

There were many similar dialogues over security and democracy. When the leader of the Free Party, Fethi Bey, was giving a parliamentary speech in which he criticized existing conditions for the improvement of democracy, another deputy responded saying, 'the alternative [to the current authoritative system] is anarchy; you want anarchy'. Yet another parliamentarian said, 'we cannot give up state authority in the name of freedom and democracy', adding that free politics would 'plunge the country into a blood bath'. Still another went further and proposed that the Free Party leadership be tried for betrayal and treason to the motherland. ${ }^{96}$

At this moment, the security process was irreversible. The dichotomous understanding about the relationship between democratization (liberalization) and the security of the nation and state, had obviously become the primary lens used by most of the elite to make sense of what was taking place. The argument boiled down to 'anarchy' vs. 'democracy'. The position of the powerful elite was best reflected in the personal situation of Mustafa Kemal. As someone who was impatient to transform his country as quickly as possible into a western nation-state with a democratic structure, he probably felt trapped. Whilst his 'youthful dreams' were of the west and their political governance techniques, and his genes from Ottoman modernization attempts forced him to go ahead with political liberalization attempts, his constant worries over keeping the state and the regime intact (particularly in consideration of the major characteristics of the previous Ottoman period of anarchy, loss of control, and ultimate defeat), kept his progressive tendencies cautious and guarded.

It was clear that Mustafa Kemal did seek solutions for this torn situation. In a newspaper article in August 1930, the idea of a kind of 'block' - which he had apparently devised - was introduced. According to the article, Mustafa Kemal would become the chair of both of the two parties, and would nominate candidates for each party's forthcoming elections. These candidates would then be elected by free elections, and the parties would be represented in parliament according to their election success. Both parties, however, would be strictly loyal to secularism and would avoid 'harmful' policies and constituents. ${ }^{97}$ This suggests that Mustafa Kemal was looking for a way of keeping political competition (seen as producing anarchy) under control, and therefore securing the system, while still maintaining an image of political plurality.

In the end, however, Mustafa Kemal apparently surrendered to his fears of security, and decided not even to opt for the 'block' idea. The security elite 
no doubt played their role in this decision. Many army commanders visited Mustafa Kemal, and revealed their ideas that the Free Party experience was having a negative impact on the army, and that if things were allowed to continue, it would become difficult for army commanders to control the situation. ${ }^{98}$ Clearly the degree of 'securitizing' the public agenda had reached such a level that the limits of even Mustafa Kemal's power were apparent. ${ }^{99}$ The situation also made clear that even the most powerful elements of the elite, those who had started the revolution, now had to respond to the needs of the increasingly consolidated and institutionalized status quo concepts and structures. We can now see at this point some kind of convergence between the interests of the consolidated elite and the continuance of the regime and the governance system as it was. In a sense, when the elite - including Mustafa Kemal - thought about the security of the regime/state/nation, they were also very much looking at the safety of their own interests and power.

Under these circumstances, the Free Party experience came to an end. Mustafa Kemal made his choice and told the Free Party leadership that he would chair the existing CHP party, and they should therefore compete against him. Fethi Bey, leader of the Free Party, said that the party had not been formed in order to fight Mustafa Kemal, and on 17 October 1930, the Free Party closed itself down. A party which had sought to introduce multiparty politics, whose ideas clearly reflected cutting-edge political freedoms and liberalization issues in western Europe, ${ }^{100}$ and whose main mission was to make Turkey's system of government as democratic as those of the European states, had fallen prey to the sometimes genuine, sometimes distorted, understandings and manipulations of the security process.

Shortly after this closure, an incident took place that provided a kind of justification to the elite who had emphasized the importance of state security and regime safety. An attempted rebellion took place in the small town of Menemen, near Izmir, where the Free Party had enjoyed significant popularity. Apparently, a religious person named 'Dervish Mehmet', taking advantage of a political environment favouring opposition, organized some pro-caliphate groups. ${ }^{101}$ On 30 December 1930, they called for a rebellion, citing the 'siege' on religion and Islam, and calling for shariat. The incident became more dramatic when the local security chief tried to stop them and was murdered. The rebels made a show of this, cutting off the man's head and carrying it around the city on a stick. Shortly thereafter, the attempted rebellion was quickly quashed, and the leaders captured, tried, and executed.

Such an incident had a huge influence on the minds of the elite. First, Mustafa Kemal and the security-minded elite who suscribed to the argument that democratic expansion would lead to anarchy, now seemed to be proved right. The security process had the evidence it sought. Second, related to the previous point, this incident was taken as an indication of the potential of the 
fragmented characteristics in, and further consolidated the national security syndrome. It became now 'obvious' to many elite minds that society was not ready to be trusted with democracy. Therefore, 'sincere feelings' about world-standard democratic values had to be at least postponed, if not sacrificed, in the name of preventing anarchy and insecurity of the regime. ${ }^{102}$ The national security syndrome now had a significant element which saw a potentially serious counter-revolution stemming from the fragmented elements of society. By this time, the Kurdish rebellions, which had characterized and led to the end of the first multi-party attempts, along with the Menemen rebellion, which justified the accumulated fear about the opposition, presented sufficient evidence and grounds to justify the view of the Turkish state elite and society that they had a real national security problem.

The 'what if anarchy comes' view had won, and, furthermore, related fears seemed even stronger after such an unfortunate outcome of a second attempt at multi-party politics. Perhaps most significantly, such a high and consolidated level of national (in)security would serve to reduce significantly the capacity of the inherently globalizing elite to push for further political liberalization attempts on its own. In other words, future political liberalization efforts would have to be initiated and strongly urged by foreign international dynamics in order for the Turkish elite to respond, and even such responses would be plagued by an ever-increasing national security syndrome. Any extension of democracy would now be postponed until political globalization once again knocked at the door of the Turkish republic.

\section{NOTES}

1. In a widely read book, Mümtaz Soysal identifies a similar dynamic (sarkaç) between poles of 'freedom' and 'authoritarianism'. He sees the ups and downs of the constitutional movements in Turkish history as indications of his proposed pendulum. M. Soysal, 100 Soruda Anayasanin Anlamı [Meaning of Constitution in 100 Questions], 9th edn. (Istanbul: Gerçek Yayınevi, 1992). Other works have looked at a similar problematic relationship between stability and democracy, see İlter Turan, 'Stability versus Democracy: The Dilemma of Turkish Politics', Dünü ve Bugünüyle Toplum ve Ekonomi, Vol.2 (1991), pp.31-53, or at a division in the Turkish state structure as a way of dealing with this problematic split, see Kemal Karpat, 'Military Intervention in Turkey: Army-Civilian Relations before and after 1980', cited in İlter Turan, 'Stability versus Democracy'; Heath Lowry, 'Betwixt and Between: Turkey's Political Structure on the Cusp of the 21st Century', in Morton Abramovitz (ed.), Turkey's Transformation and American Policy (New York: Century Foundation Press, 2000). While useful, these works have often considered stability from the perspective of political security, rather than national, and have not conceptualized the dichotomy in a systematic manner that would permit an understanding of, for example, its causes or justifications. Moreover, while recent works by this author have investigated modern implications of the dichotomy, including its effects on how Turkey has dealt with the Kurdish issue (Ersel Aydınlı, 'Between Security and Liberalization: Decoding Turkey's Political Struggle with the PKK', Security Dialogue, Vol.33 (2002), pp.209-25.) and how it can be seen as being behind the divide in Turkish 
politics over the issue of EU accession (Ersel Aydınlı and Dov Waxman, 'A Dream Become Nightmare? Turkey's Entry into the European Union', Current History, Vol.100 (2001), pp.381-8.), no works have extensively explored the relationship in historical terms.

2. For a detailed discussion see Charles Tilly, Coercion, Capital and European States, AD 990-1990 (Cambridge, MA: Basil Blackwell, 1990).

3. Mahmut II was one of the first to introduce measures aimed at restoring a more centralized power than the more 'dangerous' looking federal/confederal one.

4. Since the primary goal was to renew the state structure, the agents of this mission were the Ottoman intellectuals who had been highly associated with the state structure. These same intellectuals were identified by Şerif Mardin as being the bureaucrats. Şerif Mardin, 'Tanzimat ve Aydınlar' ['Tanzimat and Intellectuals'], in Tanzimattan Cumhuriyet'e Türkiye Ansiklopedisi [Encyclopedia of Turkey from Tanzimat to the Republic] (Istanbul: İletişim, 1985).

5. Tevfik Çavdar, Türkiyenin Demokrasi Tarihi 1839-1950 [The History of Turkey's Democracy 1839-1950] (Ankara: İmge Kitabevi, 1999).

6. Niyazi Berkes, Türkiye'de Çağdaşlaşma [Modernization in Turkey] (Istanbul: Doğu-Batı Yayınlar1, 1978), pp.128-32.

7. Bülent Tanör, Osmanll-Türk Anayasal Gelişmeleri [Ottoman-Turkish Constitutional Developments] (Istanbul: Yap1 Kredi Yayınlar1, 1998), pp.75-95.

8. The first section said basically that the Ottoman state had been very successful and powerful because it obeyed and conducted Islamic Law, and the second section says that the Ottoman state was in decline and poverty because it had become less obedient to Islamic Law. The third section follows with the argument that if correct measures are taken in the state administration, the Ottoman state, with its strong geographical position, fertile lands, and skilful people, would develop in 5-10 years' time. The fourth section lists the principles upon which the new laws would depend, and the final section prescribes the necessary steps to be taken in order to reach the desired outcomes. Several authors have analysed the above items. See for example, Stanford J. Shaw and Ezel Kural Shaw, History of the Ottoman Empire and Modern Turkey, Vol.1: Empire of the Gazis: The Rise and Decline of the Ottoman Empire, 1280-1808 (Cambridge, London, New York and Melbourne: Cambridge University Press, 1994); Sina Akşin (ed.), Osmanlı Devleti 1600-1908 [The Ottoman State 1600-1908] (Istanbul: Cem Yayınevi, 1993), and Fahir H. Armaoğlu, 19. Yüzyll Siyasi Tarihi 1789-1914 [19th Century Political History] (Ankara: Türk Tarih Kurumu, 1997).

9. Sina Akşin even argues that Mustafa Reşit Pasha, by introducing the principle of safety for lives and properties, was trying to save his own and his peers' lives and wealth. Akşin, Osmanlı Devleti, p.121.

10. S.J. Shaw and E.K. Shaw, History of the Ottoman Empire, p.60.

11. Oral Sander, Anka'nın Yükselişi ve Düşüşü: Osmanlı Diplomasi Tarihi Üzerine Bir Deneme [The Rise and Fall of the Phoenix: A Study on the Ottoman Diplomatic History] (Ankara: Ankara Üniversitesi Siyasal Bilgiler Fakültesi, 1987), pp.125-31.

12. Bernard Lewis, Modern Türkiye'nin Doğuşu [The Emergence of Modern Turkey], tr. Metin Kıratlı (Ankara: Türk Tarih Kurumu Basımevi, 1984), p.107.

13. Akşin, Osmanlı Devleti, p.122.

14. Ibid., p.130.

15. Lewis, Modern Türkiye, p.114.

16. Çavdar, Türkiyenin Demokrasi Tarihi, p.21.

17. Lewis, Modern Türkiye, p.118.

18. Ibid., p.118

19. Armaoğlu, 19.Yüzyıl Siyasi Tarihi, p.223.

20. Çavdar, Türkiyenin Demokrasi Tarihi, p.24.

21. Ibid., p.24.

22. Cited in Çavdar, Türkiyenin Demokrasi Tarihi, p.25.

23. Çavdar, Türkiyenin Demokrasi Tarihi, p.25.

24. Lewis, Modern Türkiye, p.151.

25. Çavdar, Türkiyenin Demokrasi Tarihi, p.26. 
26. This name was intended as a Turkish translation of 'Jeune Turquie', which was used by one of the movement members, Prens Mustafa Fazıl, in a letter he wrote to the Sultan from Paris. Faz1l was inspired by the popular terminology in use in Europe, such as Young Italia, Young Germany, Young France, etc. Lewis, Modern Türkiye, p.152-3. This letter not only coined the term 'New Ottomans' but also formed the basis of the programme of this society. Its content was strikingly liberal in the sense that it posited freedom as the foundation of all progress. In the same vein, the letter upheld freedom of conscience as well as secular administration and public accountability. More radically, it argued that for every country the legitimate way of governance was a constitutional arrangement. Çavdar, Türkiyenin Demokrasi, pp.27-8.

27. Akşin, Osmanlı Devleti, pp.141-2.

28. Quoted in Çavdar, Türkiyenin Demokrasi, p.27.

29. For example, by 1867, Namık Kemal, Ziya Bey, Ali Süavi, Reşat Bey, Nuri Bey, Agah Efendi, Mehmet Bey, Rifat Bey, and Hüseyin Vasfi Paşa, had all escaped to Paris. Şinasi was there from 1865 onwards. Ibid., p.28.

30. One of these foreigners was Slodyslaw Plater, a Polish nationalist and a bourgeois revolutionary. The other was Simon Deutsch of Vienna. Ibid., p.29.

31. Şerif Mardin addresses a different aspect of the change in the thinking of the Young Ottomans in this era. As he points out, the Young Ottomans also agreed that one of the major shortcomings of the Tanzimat period was that an overarching philosophy - namely, the enlightenment philosophy in the west - was seen as the primary driving force behind western parliamentarism and constitutionalism. To them, Tanzimat dismissed Islam's world view as a potential overarching philosophical perspective, and this led to a groundless and weak construction of liberal reforms. Instead, they proposed, Islamic principles could provide a philosophical platform for a democratic system. Şerif Mardin, Türk Modernleşmesi: Makaleler IV [Turkish Modernization: Articles IV] (Istanbul: İletişim, 1991), pp.185-6.

32. Erik Jan Zürcher, Milli Mücadelede İttihatçılık [Unionism in the National Struggle], trans. N. Salihoğlu (Istanbul: Bağlam, 1987), p.21.

33. Tensions in European and Ottoman relations were further heightened after the 1876 killing of German and French Consul Generals by crowds in Salonika. Lewis, Modern Türkiye, p. 158 .

34. Shaw also reports that the divinity student rebellion was provoked and designed by a liberal bureaucratic group led by Mithat Pasa. Shaw and Shaw, History of the Ottoman Empire, pp.162-3.

35. Ibid., pp.163-6.

36. Berkes, Türkiye'de Çağdaşlaşma.

37. Thus the west would be defeated by its own weapons (westernization). Aykut Kansu, '20. Yüzyıl Başı Türk Düşünce Hayatında Liberalizm' ['Liberalism in Early 20th Century Turkish Thought'], in Tanıl Bora and Murat Gültekingil (eds.), Modern Türkiye'de Siyasi Düşünce [Political Thought in Modern Turkey], Vol.1, (Istanbul: İletişim Yayınları, 2001).

38. Cited in Lewis, Modern Türkiye, p.153.

39. Armaoğlu, 19. Yüzyıl Siyasi, p.222.

40. Çavdar, Türkiyenin Demokrasi Tarihi, p.37. Rumeli referred at the time to the European side of the Ottoman Empire.

41. Tanör, Osmanll-Türk, pp.128-29.

42. Çavdar, Türkiyenin Demokrasi Tarihi, p.39.

43. Heyet-i Mebusan, which can be compared to the House of Commons in a bicameral system, could propose laws only in areas falling within its jurisdiction, and these areas were not clearly defined in the 1876 constitution. When this assembly drafted a law, it was supposed to be approved first by the upper chamber of the parliament and then by the Sultan. Rejection by either of these two meant that the law would be abandoned. Tanör, Osmanl Türk, pp.141-44.

44. These rights included, first and foremost, the equality of all Ottoman subjects before the law. Arbitrary punishment outside the rule of law was prohibited. In addition to the security of life, the security of property principle was adopted within the new constitution. No 
longer could property be confiscated by the state unless it was compensated or confiscation was legally justified. Likewise, the taxation system would be rearranged on a more just basis to include all Ottoman subjects. Ibid., pp.145-7.

45. Articles 109 and 110 were included at the insistence of Prime Minister Mithat Pasha, because of his governorship experience. S.J. Shaw and E.K. Shaw, History of the Ottoman Empire, p.178.

46. Unlike its predecessor in 1876, the new constitution protected individuals not only from arbitrary punishment but also from arbitrary arrest. The infamous Article 113 of the previous constitution, which subjected all rights and liberties to the Sultan's will, was excluded from the new constitution. It still did not allow full freedom of thought, but introduced certain measures on the way to freedom of the press. In addition, freedom of association was institutionalized with the new constitution, though in a limited fashion. Tanör, Osmanll-Türk, pp.196-97.

47. Tanör gives a nice account of how this organization used terrorizing tactics in order to control everything. The central committee of the party became the seed of an iron core in the whole Ottoman state - sometimes well hidden, and sometimes overt. Ibid., pp.202-7.

48. Ibid., p.198.

49. Fuat Keyman raises a somewhat similar point in his discussion on Turkish nationalism. Turkish nationalism, in line with other Third World nationalisms, possesses an inherent dilemma. The crux of the dilemma is that while it is fiercely anti-imperialist Turkish nationalism at the same time accepts the normative and epistemological dominance of the west as evident in the project of modernization/ westernization it embarked upon. For more information see, Fuat Keyman, 'On the Relation between Global Modernity and Nationalism: The Crisis of Hegemony and the Rise of (Islamic) Identity in Turkey', New Perspectives on Turkey, Vol.13, Fall (1995), pp.93-120.

50. A 'securitization process' can be considered as a process of security becoming the lens through which all issues are viewed. During such a process, an increasing primacy of security over all other issues can be seen.

51. Erik Jan Zürcher, Modernleșen Türkiye'nin Tarihi [Turkey, A Modern History], 3rd edn. (Istanbul: İletişim, 1998), pp.233-4.

52. Quoted in Çavdar, Türkiyenin Demokrasi Tarihi, p.264.

53. Çavdar reports a speech by a constituent representative of the government, Recep Bey, who says that he carefully followed the opposition's speeches and noted that "not once did they mention the word Republic'. Ibid., p.264.

54. Ibid., p.265.

55. Ibid.

56. Ibid.

57. The chairman was Kazım Karabekir Paşa, deputy chairs were Dr Adnan and Rauf Bey, the General Secretary was Ali Fuat Paşa, and the board included Muhter Bey, İsmail Canpolat, Halis Turgut, A. Şükrü Bey, Necati Bey, Faik Bey, and Rüştü Paşa.

58. Ahmet Yeşil, Terakkiperver Cumhuriyet Fırkası [Progressive Republican Party] (Ankara: Cedit Neşriyat, 2002), p.446.

59. Çavdar, Türkiyenin Demokrasi Tarihi, p.266.

60. He reportedly said that he would not 'shed blood unnecessarily'. Ibid., p.277.

61. For a thoughtful analysis by an army officer of the rebellions made during the republican era, see Reşat Hall1, Türkiye Cumhuriyetinde Ayaklanmalar 1924-1938 [Rebellions in the Turkish Republic 1924-1938] (Ankara: Genel Kurmay Harp Tarihi Başkanlığı, 1972).

62. Yeşil, Terakkiperver, pp.404-27.

63. For the negotiations over the decision to declare emergency law, see Turkey, Turkish Grand National Assembly, TBMM Zabit Ceridesi [Minutes of the Turkish Grand National Assembly], vol.14, session 4, (25 Feb.1925), pp.306-9.

64. Çavdar, Türkiyenin Demokrasi Tarihi, p.276. Mustafa Kemal's responses to these telegrams were issued in the newspapers. Anadolu News Agency (Ankara), 26 Sep.1925.

65. Ibid., p.277.

66. For the three brief points made in this law, see Zafer Üskül, Siyaset ve Asker [Politics and the Army] (Ankara: İmge Kitabevi, 1997), p.88. 
67. These quotes of Feridun Fikri Bey, Hulusi Turgut Bey, and others, as well as further details of the liberal parliamentarians' arguments, can be found in Mete Tunçay, Türkiye Cumhuriyetinde Tek Parti Yönetiminin Kurulması 1923-1931 [The Establishment of OneParty Rule in the Turkish Republic 1923-1931] (Ankara: Cem Yayınevi, 1981), pp.142-3.

68. This interpretation is also implied in Üskül, Siyaset ve Asker, p.82.

69. These included 'Tevhid-I Efkar', 'Son Telegraf', 'Istiklal', 'Sebilurreşat', 'Aydınlık', 'Sadayıhak', 'Sayha', and 'İstikbal.' Tunçay, Türkiye Cumhuriyetinde, pp.142-6.

70. Çavdar, Türkiyenin Demokrasi Tarihi, p.281.

71. One example of this was the wide and arbitrary naming of suspects for an assassination attempt on Mustafa Kemal in June 1926. The law was then used to try, dismiss, and discredit many opposition figures. For details on the assassination attempt and its implications see Ergun Aybers, 'İstiklal Mahkemeleri 1923-1927' ['War-time Tribunals 1923-1927’] (Ph.D. Thesis, Ankara Üniversitesi, 1979).

72. A fascinating example of how the extraordinary tribunals acted virtually on behalf of the government is shown in the case of a private letter from a member of the East Revolution Court, in which he tells how diligently he is working to 'punish the journalists in the area'. He ends the letter by asking for his 'new orders' and for the route that he should follow to do his job better. Çavdar, Türkiyenin Demokrasi Tarihi, p.282.

73. Tunçay seems quite sure that Mustafa Kemal, with his well-known pragmatism, must have organized and supported the formation of the Free Party in order to make the potential societal opposition more focused, and therefore more visible and controllable. Tunçay, Türkiye Cumhuriyetinde, p.249.

74. In a memoir by one of the leading figures in the Free Party, the author indicates that during the course of events, he and some other Free Party leaders were not really sure of Atatürk's true position in terms of his promotion of their party, and were concerned that they were

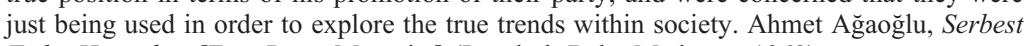
Firka Hatıralarl [Free Party Memoirs] (Istanbul: Baha Matbaası, 1969).

75. Ibid., p.64.

76. Turkey, Turkish Grand National Assembly, TBMM Zabit Ceridesi [Minutes of the Turkish Grand National Assembly], vol. 22, session 1, 1 Nov.1930, p.3.

77. This atmosphere among the Turkish elite and, in particular, with Mustafa Kemal, was reported by the then American Ambassador to Turkey, J.C. Grew, Turbulent Era (Cambridge: Houghton-Mifflin, 1952), p.869.

78. Tunçay, Türkiye Cumhuriyetinde, pp.245-6.

79. Ahmet Ağaoğlu, Serbest Fırka, p.8.

80. Ibid., p.11.

81. Tunçay, Türkiye Cumhuriyetinde, p.252.

82. Fethi Okyar, Serbest Cumhuriyet Firkası Nasıl Doğdu Nasıl Feshedildi [How was the Free Republican Party Born and Dissolved] (Istanbul: n.p., 1987), p.443. Also see Furuzan Hüsrev Tökin, Türkiye'de Siyasi Partiler ve Siyasi Düşüncenin Gelişmesi 1839-1965 [Political Parties and the Development of Political Thought in Turkey 1839-1965] (Istanbul: Elif, 1965), pp.74-5.

83. Son Posta (İstanbul), Yarın (İstanbul), and Halkın Sesi (İstanbul). Tunçay, Türkiye Cumhuriyetinde, p 257.

84. Fethi Okyar even reports that the father of a child, who was killed in clashes between Free Party supporters and government representatives, said to him that the dead child was his sacrifice to save the people from the current administration. Okyar, Serbest Cumhuriyet, p.448.

85. Çetin Yetkin, Serbest Cumhuriyet Fırkası Olayı [Free Republican Party] (Istanbul: Özal Matbaas1, 1982), p.111.

86. İsmet İnönü, Hatıralar [Memoirs] (Ankara: Bilgi Yayınevi, 1985), pp.229-30.

87. Tökin, Türkiye'de Siyasi, pp.74-5.

88. Hilmi Uran, Hatıralarım [My Memoirs] (Ankara: Ayyıldız Matbaası, 1959), p.219.

89. Fethi Okyar himself admits that, even to his own surprise, it appeared that the Free Party was getting overwhelming attention from society, and this panicked the ruling elite, since it threatened their status and power. Okyar, Serbest Cumhuriyet, pp.490-91. 
90. These deputies had formal and informal ties to the different executive branches of the state, for example to MPs who were on the Committee for Internal Ministry Supervision. Ahmet Ağaoğlu, Serbest Furka, p.28.

91. Tunçay, referring to Okyar, points out that the Free Party, in order to avoid the enmity of the state apparatus, guaranteed the presidency of Mustafa Kemal. Tunçay, Türkiye Cumhuriyetinde, $\mathrm{p} 254$.

92. It is even reported that government agents tried to physically block the society from showing their support for the new party. Ibid., p.41.

93. One leading CHP member, Cevdet Kerim İnceday1, accused the Free Party leadership of 'betrayal to the motherland'. Ibid., p.45.

94. Yunus Nadi, 'Atatürk'e Açık Mektup' ['Open Letter to Atatürk'] Cumhuriyet (Istanbul), 9 September 1930. For Atatürk's response to this letter see, Cumhuriyet (Istanbul), 10 Sep.1930.

95. Ahmet Ağaoğlu, Serbest Firka, pp.63-64.

96. Turkey, Turkish Grand National Assembly, TBMM Zabit Ceridesi [Minutes of the Turkish Grand National Assembly], Vol.22, session 1, (1 November 1930), pp.16-23.

97. Milliyet (Istanbul), 5 Aug.1930.

98. Ahmet Ağaoğlu, Serbest Firka, p.77.

99. It was reported at the time that at least one of Mustafa Kemal's closest friends said at a dinner party that if it were necessary, 'they' would even fight against Mustafa Kemal himself, in the name of the security of the republic. Ibid., p.71.

100. These were more or less outlined by Fethi Bey during his famous Izmir visit, when he described European progress as the result of 'a balanced combination of capital and labour in a very free competition', free politics, a liberalism that 'leaves people's issues to the people', individual initiatives and a well-defined state role. Çavdar, Türkiyenin Demokrasi, p.300.

101. These were religious circles that were opposed to the new secular reforms, and which sought to overthrow the secular administration and reinstate the Caliphate. Neşet Çağatay, Türkiye'de Gerici Eylemler: 1923ten Bu Yana [Regressive Activities in Turkey: From 1923 until Today] (Ankara: Ankara Üniversitesi Yayınları, 1972), pp.33-34.

102. Tarık Zafer Tunaya, Türkiye'de Siyasal Partiler, 1859-1952 [Political Parties in Turkey, 1859-1952] (Istanbul: Doğan Kardeş Yayınları, 1952). 